\title{
NGOs and the Democratization of Ecuadorian Water Governance: Insights from the Multi-Stakeholder Platform el Foro de los Recursos Hídricos
}

\author{
Jaime Hoogesteger
}

Published online: 11 March 2015

(C) The Author(s) 2015. This article is published with open access at Springerlink.com

\begin{abstract}
NGOs have taken up an increasing number of roles and responsibilities in Latin American societies. Based on a study of the multi-stakeholder platform, the Water Resources Forum in Ecuador, this paper shows how through the creation of a broad network of NGOs, academics, grassroots water users organizations and governmental actors; this platform has been able to contribute to the democratization of water governance. This paper analyses the international and national sociopolitical context in which this platform developed and traces the history and strategies that marked its development. Based on this, it argues that NGOs can play an important role in the development of more democratic and inclusive public policy making in water governance, but that the capacity of NGOs to bring about change greatly depends on the socio-political context and on the networks they are able to forge with grassroots organizations, state agencies, funders and other third sector actors.
\end{abstract}

Résumé Les ONG endossent un nombre croissant de rôles et de responsabilités dans les sociétés latino-américaines. S'appuyant sur une étude de la plateforme multipartite du Forum des ressources en eau en Équateur, cet article montre comment grâce à la création d'un vaste réseau d'ONG, d'universitaires, d'organisations populaires d'utilisateurs d'eau et d'acteurs gouvernementaux, cette plateforme peut contribuer à démocratiser la gouvernance de l'eau. Cet article analyse le contexte sociopolitique national et international dans lequel cette plateforme s'est développée et retrace l'histoire et les stratégies qui ont marqué son développement. S'appuyant sur cette analyse, il fait valoir que les ONG peuvent jouer un rôle important dans l'élaboration de politiques publiques plus démocratiques et plus inclusives dans la gouvernance de l'eau, mais que leur capacité à apporter des

\footnotetext{
J. Hoogesteger $(\bowtie)$

Water Resources Management Group, Wageningen University, Postbus 47, 6700 AA Wageningen, The Netherlands

e-mail: jaime.hoogesteger@wur.nl
} 
changements dépend dans une large mesure du contexte sociopolitique et des réseaux qu'elles sont capables de forger avec les organisations locales, les organismes publics, les bailleurs de fonds et les autres acteurs du tiers secteur.

Zusammenfassung Nicht-staatliche Organisationen haben in lateinamerikanischen Gesellschaften zunehmend mehr Funktionen und Aufgaben übernommen. Beruhend auf einer Studie der Multi-Stakeholder-Plattform, dem Water Resources Forum in Ecuador, zeigt dieser Beitrag, wie diese Plattform durch die Schaffung eines breiten Netzwerks von nicht-staatlichen Organisationen, Akademikern, Basisorganisationen für Wasserverbraucher und Regierungsakteuren zur Demokratisierung des Wassermanagements beitragen konnte. Die Abhandlung analysiert den internationalen und nationalen sozio-politischen Kontext, in dem sich diese Plattform entwickelte, und verfolgt die Geschichte sowie Strategien, die ihre Entwicklung kennzeichneten. Es wird sodann dargelegt, dass nicht-staatliche Organisationen eine wichtige Rolle bei der Entwicklung einer demokratischeren und integrativeren Gestaltung des öffentlichen Entscheidungsprozesses im Wassermanagement spielen kann; ihre Fähigkeit, Änderungen herbeizuführen, dabei jedoch sehr vom sozio-politischen Kontext und den Netzwerken, die sie mit Basisorganisationen, staatlichen Einrichtungen, Geldgebern und anderen Akteuren im Dritten Sektor formen können, abhängt.

Resumen Las ONG han asumido un creciente número de papeles y responsabilidades en las sociedades latinoamericanas. Basándose en un estudio de la plataforma multi-actores el Foro de los Recursos Hídricos en Ecuador, el presente documento muestra cómo, mediante la creación de un amplia red de ONG, académicos, organizaciones de base usuarias de agua y actores gubernamentales, esta pltaforma ha podido contribuir a la democratización de la gobernanza del agua. El presente documento analiza el contexto sociopolítico nacional e internacional en el que se desarrolló esta plataforma y presenta la historia y estrategias que marcaron su desarrollo. Basándose en esto, argumenta que las ONG pueden desempeñar un importante papel en el desarrollo de políticas públicas más democráticas e inclusivas en la gobernanza del agua pero que la capacidad de las ONG para generar cambios depende en gran medida del contexto sociopolítico y de las redes que puedan forjar con organizaciones de base, agencias estatales, financiadores y otros actores del sector terciario.

Keywords NGOs · Grassroots organizations $\cdot$ Multi-stakeholder platforms · Water governance $\cdot$ Ecuador

\section{Introduction}

When the president of the National Constituent Assembly of Ecuador, architect Fernando Cordero, presented the final draft of the Ecuadorian Constitution in July 2008, he proclaimed 'This Constitution is made of water' (García 2010). It included 
a large number of progressive articles related to water and its management, of which the most celebrated ones are the recognition of the human right to water, the prohibition of all form of water privatization, citizens participation in water governance and the recognition of 'nature's' water rights (Harris and Roa-García 2013; Roa-García et al. 2013). Such a 'wet' Constitution resulted, for a great part, from the prolonged and steady presence and involvement in the national political arena of the third sector represented by committed individuals, NGOs and social movement organizations with visions of a better, more just and sustainable society (Andolina et al. 2009; Hoogesteger 2014; Jameson 2011). Many of the articles that were included in the Constitution came directly from proposals of NGOs and grassroots organizations as attested by García (2010) who states that

The achievements in the Ecuadorian Constitution of 2008 with regards to issues on water are not the property or legacy of any single organization, institution or platform in particular; it has no owners nor proprietors. To have such a 'wet' Constitution is the result of accumulated social and political histories over the past twenty years... (p. 174)

In this article, I trace the origins, constituency and development of el Foro de los Recursos Hidricos (Water Resources Forum, WRF), ${ }^{1}$ one of the policy advocacy platforms that played an important role in the definition of many of the water related articles of this Constitution. I describe the context, main actors and dynamics that have made WRF a nationally recognized multi-stakeholder platform that critically analyses Ecuadorian water governance with the aim to develop new and progressive policy proposals. I show that this broad-based platform, its development, activities and proposals are propelled and coordinated by national development NGOs that have skilfully articulated to grassroots organizations, other third sector and state organizations. Based on this case, I argue that NGOs that closely articulate to grassroots and other non-governmental organizations through extensive multi-actor networks can play an important role in the democratization of governance by forming, within civil society, a critical and proactive network that through different means participates in governance and policy debates.

The data of this research were gathered through fieldwork in Ecuador. The study is based on qualitative data and follows an interpretive approach, which considers the meanings and interpretations given by social actors to their context and actions (including those of others) as constituting their social reality (Mason 2002). Data gathering consisted of over sixty in-depth semi-structured interviews, participation, observation and active involvement in the activities of the described institutions (formal and informal meetings, capacity building programmes, workshops and public events) between 2008 and 2013. This primary material was supplemented by reviewing secondary data and newsletters published by WRF. Through the research design, which was informed by a respondent driven sampling methodology (Heckathorn 1997), data were gathered from within an existing network of actors that included high state officials, researchers, NGO personnel and leaders and members of grassroots organizations. The data from the different information

\footnotetext{
1 See www.camaren.org/foro-de-los-recursos-hidricos/.
} 
sources and research methods were triangulated to corroborate findings and test their validity (Lincoln and Guba 1985).

In what follows, I first present an short discussion on the role and position of NGOs in the development of the global South. Second, I focus on the role development NGOs have played in water governance in the Andean region of Latin America. Then, I present the socio-political context in which the basis for WRF was established. In subsequent sections, I first analyse the rise, development and networks of WRF by focusing on its relations with external agents. After this, I focus on the socio-political context and strategies that enabled WRF to importantly contribute to the 'wet' Ecuadorian Constitution of 2008. In the last section before the conclusions, I present the challenges the present international context has brought to WRF. In the conclusions, based on the case of WRF, I reflect on the potential roles and limitations of NGO involvement in the democratization of societies in Latin America.

\section{NGOs and Development in the Global South}

NGO have received much attention in the literature since the 1980s; much of which has lauded these 'new' actors as the institutional 'alternative' to existing development approaches (Mitlin et al. 2007; Srinivas 2009). Much of the literature stresses the importance of NGOs and attributes them 'new' roles in poverty alleviation, provision of services, civil society empowerment and democratization (Kilby 2006). Resultantly, at international level, NGOs have been recognized as key actors for pursuing established international developmental goals (Brinkerhoff et al. 2007).

Most NGOs that work on development challenges in the global South frame themselves as part of civil society, in which they play an empowering and representative role through which they advance what they see as broader community interests (Sacouman 2012). Nevertheless, most NGOs are not membership based, financed or governed (Fowler 2000). Rather as Kilby (2006) points out 'NGOs are largely guided and driven by staff, self-appointed Boards, or very small numbers of formal members; and the driver for their work emerges generally from a religious or ethical base-their values' (p. 952). Most are dependent on external funding agencies, are formally registered by the state and adopt non-violent approaches to their work.

As such, Kilby (2006) argues that development NGOs can be defined as public benefit organizations that work as voluntary, self-governing independent bodies that operate on the basis of values or shared interests and which Bebbington (1997b) describes as

... private, professionally staffed, non-membership and intermediary development organisations, [...] created from the mid-1960s through to the mid1980s that were founded on the basis of a commitment to an alternative, more democratized and inclusive development (p. 1756). 
According to Uvin and Miller (1996), the rise of NGOs on a large scale 'parallels a slow but profound change in the international development aid system' (p. 344) and responds to the internationally increased attention for 'less state' and more 'bottom-up; market based' development and increasing levels of civil society participation in issues concerning their own development. This international trend, which was supported and greatly promoted by the World Bank and other international organizations and donors (Andolina et al. 2009; Brown and Kalegaonkar 2002; Yashar 2005), has gone hand in hand with a search for another form of development which Petras and Veltmeyer (2006) describe as follows:

a widespread search for "another form of development," a decentralised and participatory form of local development based on more sustainable forms of "democratic" or "good" governance. The result has been a veritable flood of proposals and alternative models for bringing about "development" on the basis of social capital, i.e., though the agency of "self-help" of communitybased or grassroots organisations, with the assistance and support of partner institutions and "international cooperation" for development (p. 87).

Brown and Kalegaonkar (2002) argue that beyond the trends in international NGO policy, the evolution of development NGOs is also importantly shaped by the interplay of global forces, the national context and how these affect the "political, economic, and social forces that operate in the long term' (p. 232). In this context, these same authors identify four critical 'external' challenges which NGOs have to face and which I use to analyse the development of WRF and its struggles for the democratization of Ecuadorian water governance. These challenges are

(a) Relations with international actors The most challenging international relations for local development NGOs are often those with international funding agencies. In this context, the increased globalization of NGO funding and international policies has to a certain extent (re)shaped NGOs, their activities and lines of accountability in the global South (Brown and Kalegaonkar 2002; Brown 2014; Mitlin et al. 2007). Southern development NGOs have been faced with the fact that many funding opportunities are directly related to the internationally prevailing ideas and rules; many of which have been dominated in the last decades by ideas inspired in neoliberalism (Dagnino 2007; Edelman 1999; Petras 2008). However, and the same time, as Mitlin et al. (2007) point out, global NGO networks are not necessarily characterized by uneven North-South relations, and many NGOs around the world have developed their own strategies to resist, use and manoeuvre international pressures and demands.

(b) Legitimacy and accountability with the general public Sometimes there is little public understanding for the work and forms of operation of NGOs. Uncertainty about their funding sources, their motivations (religious and/or political), alliances and their local legitimacy sometimes makes it hard for NGOs to gain public legitimacy. The fact that the constituent base and governing body of development NGOs are often very narrow, just as their (inter)national funding sources, can also create problems around the public 
acceptance of their role(s), perspectives and activities (Brown and Kalegaonkar 2002; Brown 2014), which is sometimes aggravated by the difficulty of measuring the impacts of their work in clear and simple terms. Another sometimes problematic issue is that NGOs are often in first instance accountable to those who provide funding, and only in second instance to the beneficiaries of their activities.

(c) Relations with institutions of the state Governments create and control the political and legal contexts within which development NGOs can work within national or regional administrative boundaries. Some governments facilitate NGO operations, fund their activities and closely work with them, while others are suspicious of their work, funding and political motivations and might consider them as competitors in services delivery, as critics of state policies and programmes, and/or as agents of international donors and interests (Brown and Kalegaonkar 2002; Mitlin et al. 2007). This has made the relation between NGOs and national governments both a threat and an opportunity for the advancement of development NGO programmes.

(d) Relations with institutions of the market Just as with the relations with governments, some development NGOs become very critical of the private businesses and their operations, while others have come to see these as funding sources and/or as partners for the advancement of development goals.

\section{Development NGOs' Democratization Efforts in Ecuadorian Water Governance}

From the mid-1980s on, many European donor agencies focused on funding NGOs that worked on making the rural poor the agents of their own development (Bebbington 1997a; Bebbington and Farrington 1993; Perreault 2003). Many such development NGOs focused on fostering development by strengthening local representative grassroots institutions (Biekart 2007). Through increased participation from grassroots organizations, empowered social actors were expected to positively contribute to the transformation of their societies by increasing the levels of democracy, transparency and accountability through mechanisms of social control (Bebbington 1997b, c; Mitlin et al. 2007).

Since the 1980s, the Andes became a 'hot spot' for international donors, development organizations and NGOs. Non-governmental sources of support and international development funds streamed into Bolivia, Peru and Ecuador (Bebbington 2004). There is great variety and diversity in the orientation and goals of funders and NGOs that became active in the developmental domain. For instance, some funders and NGOs are ideologically grounded in Marxist ideas and have been engaged in anti-neoliberal political activism, others have come forth from church organizations, others have actively promoted the co-production of grassroots organizations as a means towards a more democratic civil society (Bebbington 1997a; Becker 2008; Hoogesteger 2012) and others have promoted the advancement of capitalist and market-environmentalist ideas such as payment for environmental 
services (Boelens et al. 2014). Their scale of operation also varies greatly and ranges from international networking activities and programmes to very localized small community projects.

In Ecuadorian water governance, NGOs have played an important role in the creation of water user organizations and their broader networks and alliances (Hoogesteger 2012, 2013a). Just as in the case of the Bolivian irrigators movement (Assies 2003; Perreault 2006, 2008), and many peasant and agrarian movements in Latin America (Borras et al. 2008; Edelman 2008), in Ecuador, developmental and environmental NGOs have come to play a key role in the consolidation of water users organizations, federation and inserting these in broader multi-actor networks (Boelens 2002, 2008b; Boelens et al. 2010). The NGOs studied in this article concern NGOs that, although parting from sometimes different ideological groundings, have been committed to the political and economic empowerment of peasant and indigenous communities as a means of democratization. Their strategy to do so has been to support the development of rural peasant livelihoods and the coproduction $^{2}$ of organizational structures of representation. These organizations are co-produced to, at local level, provide a service to their constituents (Ostrom 1990) and to develop political agency at broader scales. Processes of co-production not necessarily imply the direct involvement of the state (even though the state is somehow always there through legal and institutional frameworks)(Mitlin 2008).

Although NGOs were involved in the co-production of community managed irrigation systems in the Ecuadorian Highlands since at least the 1970s (Boelens 2008a), since the 1990s, some of these same NGOs engaged in setting up and strengthening water user associations in state-managed irrigation systems (Hoogesteger 2013a, b). This was the result of the growing international and national recognition that irrigation management, even of the large state built and state-managed irrigation systems, could best be done by water user associations (Tiaguaro-Rea 2012; Rap 2006). International funders financed these interventions in the irrigation sector through NGOs and other non-state actors (often private companies) that took over some of the tasks that had for decades been the state domain (Cremers et al. 2005). These policy changes were the result of a search from international funders and many development aid agencies to reduce state expenditure in the irrigation sector (Tiaguaro-Rea 2012; cf. Suhardiman and Giordano 2014). As is exposed below, these changes brought about an increased involvement of the third sector in Ecuadorian water governance. Although the involvement of the third sector increased above all at irrigation system level, it was also involved in efforts to up-scale water users representation and participation at regional, provincial and national levels (see Hoogesteger 2014; Andolina 2012; Carroll and Bebbington 2001). In this contribution, I focus specifically on the increased involvement of NGOs and user based federations in the Ecuadorian national policy domain as is explained below.

\footnotetext{
${ }^{2}$ Co-production is defined as the coordinated joint efforts between a) state and/or development NGOs and, b) local peasant and indigenous communities, for the establishment of representative grassroots organizations (See Hoogesteger 2013c).
} 


\section{Neoliberalism, the State and NGOs in Ecuadorian Water Polices of the 1990s}

In Ecuador, the process of economic integration and neoliberal restructuring, which started in the early 1980s, reconfigured the social and political landscape (Hey and Klak 1999). Amidst a period of political instability, economic recession, soaring inflation rates and socio-political turmoil between 1990 and 2000, water policies and regulations shifted roles and responsibilities from national to local governments, private service providers and water users associations while also changing the institutional and legal setup (Cremers et al. 2005). In 1993, the Law of State Modernization, Privatization and Provision of Public Services was enacted, opening the doors for far-reaching national water reforms and an increased involvement of the private and third sector in water governance. It paved the way for institutional reforms in 1994 (see Boelens et al. 2013) and the implementation of a World Bank financed Irrigation Management Transfer programme between 1995 and 2001. Through this programme, three private international consortia of consultancy companies transferred 35 formerly state managed irrigation systems (out of the 79) to newly created local water user associations (Hoogesteger 2013b). In parallel, several internationally funded national and international NGOs engaged in programmes to strengthen and consolidate local water users organizations and federative initiatives (Hoogesteger 2012; Hoogesteger 2013a). In January 1996, the National Consultative Water Council resolved that water permits could be given indefinitely by the state. At the same time, it enabled marketable water transfers and the privatization of water services delivery as happened with the water and sanitation services of the cities of Guayaquil and Machala (Fernández and Buitrón Cisneros 2012; FORO 2005). In 1998, the 'new' Ecuadorian Constitution further entrenched some of the neoliberal water governance premises (Cremers et al. 2005).

In an Ecuadorian context of a retreating state, economic recession and widespread levels of rural poverty and marginalization, NGOs fit well with some of the neoliberal ideas that dominated policy making (Andolina et al. 2009, cf. Dagnino 2007). First, with private and/or international funds, they took over many functions that had hereto been done by the state. Second, NGOs competed with each other both locally as well as internationally for (private and public) funds for the execution of local development projects. Third, NGOs as project executers were often more flexible and competitive than state agencies while also being tightly held accountable for in terms of resource spending and project implementation. Finally many NGOs stimulated empowerment and self-help of the marginalized groups, making them responsible for their individual and sometimes collective livelihoods and institutions through the introduction of economic rationality and systems to guarantee transparency and accountability. An ideology which fit well with liberal ideas of individual freedom and responsibility (Andolina et al. 2009). In this sense for instance, Alvarez et al. (1998) question whether NGOs did not become neo- or para- rather than non-governmental organizations that help to reinforce a public sector displaced by the state. In this context, the Ecuadorian government greatly facilitated and applauded the activities of international donors and development 
NGOs in the country. As a result the World Bank, the Dutch-based Netherlands Development Organization (SNV), the Swiss Agency for Development and Cooperation (COSUDE), the American CARE foundation and other international funding agencies and NGOs found fertile grounds to advance their interests in the poverty stricken Ecuadorian Andes (Andolina et al. 2009; Carroll and Bebbington 2001). They did so by financing and collaborating with national NGOs that actively engaged in the irrigation sector such as the Ecuadorian Central for Agricultural Services (CESA), the Institute of Ecology and Development of the Andean Communities (IEDECA), the Ecuadorian Fund Populorium Progressio (FEPP) and others which established the basis for the creation and consolidation of the WRF as is explored below.

\section{Co-producing a National Multi-Stakeholder Platform with International Support}

The origins of WRF can be traced back to the early 1990s when with international funding both the Swiss (COSUDE) and the Dutch government (DGIS) tried to develop a capacity building programme for state employees, practitioners and community leaders in the field of natural resources management in Ecuador. This initiative was coordinated with the Ministry of Agriculture, Livestock, Aquaculture and Fisheries (MAGAP) and the local branch of the Food and Agriculture Organization of the United Nations (FAO). The evaluation of this initiative was negative and prompted an alternative for organizing the envisioned capacity building programmes. ${ }^{3}$ Under the leadership of NGOs and with the auspices of MAGAP, the initiative was reinvigorated. To do so, in 1995, the inter-institutional Consortium for Capacity Building for the Management of Natural Resources (CAMAREN) was co-produced based on the joint effort of national NGOs, international funding agencies and national state agencies. Its members were six NGOs, ${ }^{4}$ MAGAP and the governmental Advisory Commission of the Environment (Comisión Asesora Ambiental, CAM). Its constituents defined that CAMAREN would work on the principle of making capacity building programmes based on the experiences that NGOs had accumulated through their projects and programmes. Five capacity building programmes were identified which were irrigation, domestic water supply, management of páramos, ${ }^{5}$ soil management and agroforestry. The

\footnotetext{
3 Personal communication of the founders of the WRF (interviews held in Spring 2011, Quito).

4 CAAP (Centro Andino de Acción Popular), RAFE (Red Agroforestal Ecuatoriana), CESA, CECCA (Centro de Educación y Capacitación del Campesinado de Azuay), FEPP and CARE. Later other institutions also became members of CAMAREN including IEDECA, CICDA-AVSF, FUNDES, IEE, the Universities of Cuenca and Loja and the Ministry of the Environment.

5 Páramos are high Andean ecosystems. They are found between the continuous forest line and the permanent snowline. Its vegetation is composed mainly of giant rosette plants, shrubs and grasses.
} 
programmes were inspired on Paulo Freire's ideas on education and were designed so that they could be implemented in different parts of the country, where relevant experiences could be visited. ${ }^{6}$

Through the implementation of these programmes, a broad network of participants and trainers quickly developed (above all in the Andes region). After 2 years, this network included numerous community leaders, over 90 institutions and more than 120 capacity builders (García 2009). This network was based on a mutual collective learning process that relied on the exchange of ideas and experiences. This network of people and institutions came to be known as the 'CAMAREN space', which, through its programmes, started to transform the way natural resources management was framed and conceived of amongst NGOs and some of the personnel of national ministries. One of the main changes it brought about was a change from a technically dominated view on natural resources management to one that included attention to gender equality, empowerment, participation and sustainability. ${ }^{7}$

In 1996, as a result of a couple of national and inter-Andean workshops on the IMT process (also financed with Dutch and Swiss funds), the Inter-institutional Forum for Irrigation (FIR) was formed. It brought representatives of water user associations, NGOs and state institutions together, with the aim of forming a multiactor platform for dialogue, analysis and the creation of proposals for irrigation management. This initiative was presided by the state agency the National Council for Water Resources (CNRH), and the secretariat was delegated to the NGO CESA. Because of a lack of action by the presidency, which was put in the hands of CNRH, the initiative fell apart. This short-lived initiative, which quickly rose and fell created the precedent for WRF. Based on (a) the evaluation of CAMAREN and (b) the networks that were created in the CAMAREN space and FIR, CAMAREN and its member organizations decided to establish a national multi-stakeholder platform (forum) with an explicit anti-neoliberal agenda (again internationally financed). This marked the beginning of WRF. ${ }^{8}$

WRF was conceived of as a plural and open platform that was formed by its participants. According to one of its founders, it aimed to bring together multiethnic groups, grassroots organizations, individuals, non-governmental organizations, state institutions and academics from the whole country to analyse, debate and create proposals for water resources management. As stated by one of the founding members and now the secretary of WRF, Antonio Gaybor, 'we started with the idea that we would create proposals and that these proposals would be taken up and defended by the member institutions and organisations...' 9 Initially, in view of this departing point, a strategic choice was made not to formalize this space as an organization but to give it the position of a multi-stakeholder platform, that conceives of itself as

\footnotetext{
6 This methodology and these capacity building programmes are still the basis of CAMAREN's capacity building programmes (see www.camaren.org/).

7 Interviews with directives of participating NGOs, water users leaders and state officials.

8 The initiative was again funded by the Swiss (COSUDE) and Dutch (DGIS) governments.

9 Interview, February 2011.
} 
... an open, democratic and plural space. In it there are participants of: popular organisations, NGOs, governmental institutions, universities, unions, water users organisations (both irrigation and domestic water supply) local and regional governments. All these participants contribute to the analysis of the situation of water resources and to the formulation of proposals to improve its management. The WRF is a space to collectively build and jointly propose alternatives for the management of natural resources. ${ }^{10}$

According to García (2009), the WRF has, through its history, gone through four different phases which are:

- Positioning of water management on the national agenda and its social legitimation (2001-2002).

- Broadening of the social and political constituency (2002-2003).

- Development of political agency through the creation of public policy proposals and the pronunciation of public statements with regards to water resources in Ecuador (2004-2006).

- The construction of public policies by including most of the proposals that had been devised in WRF in the 2008 Constitution and drafts of the national water law (2007-present).

Through these phases, WRF has come to be recognized as a critical and constructive platform at national level. ${ }^{11}$

\section{Increasing Public Legitimacy and Accountability by Broadening the Social Base}

Throughout the years, the constituency of the WRF steadily grew, especially through the increased participation of water users associations and provincial initiatives of water users federations (García 2009). ${ }^{12}$ One of the important strategies of WRF to engage in and among a multiplicity of water related stakeholders in Ecuador has been its National Assembly. The WRF National Assembly has been organized since 2002, as a national event that brings together a very broad audience of participants to debate and discuss water issues. The first National Assembly was held in 2002, with 370 participants from nine provinces of Ecuador. The National Assembly has gradually grown in size and composition of participants. The first National Assembly was dominated by representatives of NGOs and state institutions. Yet throughout the years, an increasing number of representatives of grassroots organizations (farmers unions and water users organizations of domestic water supply and irrigation systems) from throughout the country have become part of this event, while the number of representatives

\footnotetext{
${ }^{10}$ This text is placed in all of the publications that come forth from the WRF. See also http://www. camaren.org/joom_site/index.php?option=com_content\&view=section\&id=4\&Itemid=6.

11 Interviews with water users leaders, NGO representatives and state representatives.

12 Many of these new organizations became part of the network through the capacity building activities of CAMAREN.
} 
from NGOs has slightly decreased. In 2012, the seventh National Assembly of WRF was held in Quito bringing together 855 participants (the majority were water users) from 23 of the 24 provinces of the country (FORO 2013). ${ }^{13}$

In order to organize and plan the National Assembly and other WRF activities, the national platform of WRF has periodic meetings with a large number of its members. To work out proposals and analyse specific issues in depth, working groups are created from among these participants. These are commissioned to draft proposals, that are subsequently presented and discussed again in the national platform meetings ${ }^{14}$ to prepare the National Assembly which is organized around defined themes. These themes are dealt with through case studies which are presented, discussed and framed by all participants; sometimes leading to the creation of policy proposals (see for instance Gaybor 2008; FORO 2005, 2008). To disseminate the results of the discussions, popular publications have been made from every event. ${ }^{15}$ These activities have enabled WRF to (a) broaden the existing networks in the whole country and (b) learn and get to know a multiplicity of local realities, ideas and experiences which sometimes lead to concrete actions, research and proposals. For instance, the attention of WRF was drawn to the large 'water grabs' that were taking place in the Ecuadorian coastal region around banana and sugar cane plantations. For this case, first research was done, published and broadly shared (see Gaybor 2010). Later, the research results were used to substantiate the demand of WRF to revise all the water concessions (allocations) in Ecuador to ensure a socially just distribution of water, a proposal that was included in the 2008 Constitution (República del Ecuador 2008).

\section{Balancing Relationships with the Changing State}

As mentioned earlier WRF developed in an internationally and nationally favourable historical context for development NGOs in Ecuador. One of its first successes and concrete proposals were presented in 2004. After the National Assembly of WRF, a proposal for legal reforms was presented to National Congress and a broad debate against the privatization of the provision of domestic water supply services in some of the cities of the country was started (see FORO 2005). WRF publicly rejected the Free Trade negotiations that were being held with the United States of America in the early $2000^{16}$ as these included some important issues concerning water resources. In subsequent years, WRF presented new and amended proposals for a new water law to National Congress and established several positioning documents with regards to public policies and the legal frameworks around water (García 2009; Gaybor 2008; FORO 2005, 2008, 2013).

\footnotetext{
13 This event is logistically, financially and in terms of content coordinated by staff of CAMAREN and its member institutions.

14 Participant observation of the researcher in 2009-2011.

15 See: www.camaren.org/category/publicaciones/publicaciones-foro-rh/.

16 Personal communication members of WRF, Spring 2011.
} 
Showing the broad networks and recognition of WRF, this platform has been invited to all formal spaces for civil society participation in the state domain at national level. Additionally several of its members have been invited to take up important directive positions in ministries and commissions of the state. Since 2008, the most remarkable appointments are three members of WRF have been appointed Secretary of the National Irrigation Institute (INAR), the coordinator of WRF was invited to become Minister of the National Water Secretariat (SENAGUA) (but refused), and other members have been hired as consultants for SENAGUA, MAGAP and INAR. Beside these personal invitations and close relationships with high state officials, the capacity building programmes of CAMAREN have been increasingly funded by governmental agencies. Yet the most important success of WRF up until now is the inclusion of several of its proposals in the 2008 Constitution (García 2010). A process is analysed below.

\section{A Changing Political Landscape}

Rafael Correa, who promised to reverse the neoliberal model, won the presidential elections in late 2006 with the political party Alianza País. This political party promised to 'build a new fatherland (patria)' through a renewed, clearer, stronger State involvement in the country's development (de la Torre and Conaghan 2009). Already during the election campaign Rafael Correa had taken up water management and the irrigation sector as one of its important campaign issues (Boelens et al. 2013). One of the campaign promises of Rafael Correa was that of 'sowing the countryside with irrigation systems'. To fulfil this promise after his election, on 31 October 2007, INAR was created within MAGAP, through presidential decree No. 695 to

guide the planned development of irrigated agriculture, in potentially irrigable areas and promote the expansion of the irrigated area in the country, especially for the small and medium farmers; and take care of the proper administration of hydraulic infrastructure and the renewable natural resources... (Decreto Ejecutivo 695, 2007, p. 1).

A couple of months later, on 15 May 2008, through Presidential Decree No. 1088, the National Water Secretariat (SENAGUA) was created. Although it falls out of the scope of this research to investigate what the precise determinants of the creation of these two institutions were, it is interesting to note that similar proposals for the creation of these institutes had been pushed forward by WRF before and after the elections (see for instance Mosquera 2011).

The 2008 Ecuadorian Constitutional Process

Shortly after its possession of power, on 15 April 2007, the government of Rafael Correa called out for a popular consultation (referendum) on whether or not a new constitution should be made for Ecuador. With an almost $82 \%$ yes, the population voted for a new constitution (CentroCarter 2008). The new constitution would be 
written by a democratically chosen Constituent Assembly for which new elections were called out (Becker 2011).

Alianza País won 80 of the 130 seats of the Constituent Assembly in September 2007 (Machado-Puertas 2008). The success of Alianza País can be attributed amongst others to Correa's skilful promotion of popular social reforms prior to the constitutional referendum and election (Petras 2008) and to the inclusion of selected people from other political parties, as well as many from outside of the traditional political arena (Becker 2011). These included several academics, NGO-leaders and social-movement activists (Becker 2011). The president's discourses emphasized the role of democracy in decision making and pushed forward the liberal ideology of individual rights. On 29 November 2007, the Constituent Assembly was installed to start its work. According, to Becker (2011) this 'provided a critical juncture for indigenous movements by opening up a historic opportunity to decolonize the country's political structures' (p. 48). Arguably, it was not only the indigenous movement that got a great opportunity to change the country's political structures but also the whole range of organized civil society groupings.

The president of the Assembly had the conviction that the Constituent Assembly should be a space for civil society participation. ${ }^{17}$ To guide and structure this process, a special unit was created as part of the Constituent Assembly, the unit of social participation (CentroCarter 2008). This unit received and processed civil society proposals through an electronic documentation system (CentroCarter 2008). To get feedback, discussions and inputs for the different themes, this unit also coordinated forums, discussion rounds and debates in which the assembly members and 'all relevant social actors' were brought together.

As a unit, we stimulated social control and participation of the grassroots groups to change the role of these social subjects; so that they go beyond only turning in proposals to a phase in which they could really participate in the debates of the Assembly. The idea was to open the processes in the Assembly to a broader social base (Member of the unit of social participation-June, 2009).

In the participatory process, between January and June 2008, 1632 proposals were received ${ }^{18}$ by the unit of social participation, and fifty six forums were held in the whole country with an alleged participation of more than 70,000 attendants (UPS 2008).

The ways through which WRF engaged in the discussions and negotiations around the water issues that were to be included in the new Constitution were manifold. In first instance, WRF, just as CONAIE, had already presented and socialized proposals for reforming the existing water law since 2004 (CONAIE 1996; FORO 2005, 2008). In the election campaign towards the Constituent Assembly and during the process that led to the Constitution, the proposals of WRF

\footnotetext{
17 Personal communication Alberto Acosta (ex-president of the Assembly) and several of his advisors (Spring 2011).

18 Of these proposals $58 \%$ were turned in by individual citizens while the remaining $42 \%$ came from civil society organizations (UPS 2008).
} 
were formally and informally presented and explained to diverse candidates with the idea of getting them compromised for the inclusion of these principles in the new Constitution. These presentations were also made and given to the president of the Constituent Assembly, who had a strong affinity with natural resources management issues.

Second, WRF together with the Constituent Assembly organized two national conferences to collect and deliberate about the different proposals that were related specifically to water issues. These conferences, which were held in Manabí and Latacunga, were logistically and methodologically coordinated by WRF and a team of the Constituent Assembly. ${ }^{19}$

Third, WRF held its National Assembly in Portoviejo on 8 and 9 May 2008. This was organized near the city of Montecristi where the Constituent Assembly was working. Most members of the Constituent Assembly were invited to the event in which the proposals of WRF were debated and refined. At the end of this WRF National Assembly, a mobilization was organized in Montecristi in order to formally and publicly hand over the proposals of WRF to the president of the Constituent Assembly and to a delegation of about thirty of its members. The mobilizations was composed of most of the participants of the WRF National Assembly that were joined by numerous irrigators from the whole country amounting to a total of 2500 people. The proposal that was handed over included a couple of basis guiding principles, article proposals for the new Constitution and a proposal for a new water law for Ecuador ${ }^{20}$ (García 2010).

Fourth, several direct entries to members of the Constituent Assembly were used and established. With members of the Constituent Assembly who identified with the water proposals that were brought forward by civil society organizations WRF members had a couple of personal meetings to explain their proposals. These same members were often approached throughout the process to discuss specific water related issues. Another important direct entry point to the Constituent Assembly members were their advisors. Many of them were linked to the network of WRF, came from the NGO sector, and played a key role in the articulation of many of the articles and how these were framed and defended in the plenary discussions. In this way, a constant pressure was excreted to include the demands that had been brought forward by WRF. As mentioned by one of the assembly members

WRF was there daily insisting in a very specific manner about the issues and articles related to water. I think this is a fundamental element. It enabled to importantly complement the articles on water in the Constitution (June 2009).

The draft constitution that was presented to the new president of the Constituent Assembly, Fernando Cordero, in July 2008, contained many progressive articles that were related to water resources. The most important proposals that had been presented by WRF (and some of these proposals were much more broadly shared within the Ecuadorian water users movement) were included in the constitution. These included the human right to water, water as national strategic heritage of public use, exclusivity

19 Participation in the Latacunga conference and interviews members of WRF.

20 Personal communication members WRF, Alberto Acosta and advisors of the Constituent Assembly. 
Table 1 Main principles that were incorporated in the 2008 Constitution (own elaboration)

\begin{tabular}{lc}
\hline Principle & Articles \\
\hline Water as a human right & 12 and 66 \\
Water as strategic national heritage of public use & 318 \\
Public and community-based water management & 318 \\
Establishment of allocation priorities: (1) human consumption, (2) irrigation for & 318 \\
$\quad$ national food sovereignty, (3) ecological flows, (4) productive uses... & \\
Social participation in decision making & $85,95,96$ \\
Draughting of a new water law for Ecuador & Temporary \\
& disposition 1 \\
Revision of private domestic water supply companies & Temporary \\
Redistribution of water resources & disposition 26 \\
& Temporary \\
\end{tabular}

of public and community organizations to manage water resources (no private water providers), establishment of water allocation priorities, the establishment of a single national water authority, social participation in decision making and the redistribution of water resources based on principles of social equity (see Table 1) (also see Acosta 2010; García 2010; Republic of Ecuador 2008).

The final approval of the constitution through a referendum in September 2008 was greatly supported by most social groups and many WRF members.

The efforts of WRF were important for the definition of some articles and principles of the new constitution, but these were only a small part of the larger lobby of very diverse organizations that form the Ecuadorian water users movement. A large number of NGOs and grassroots organizations, as well as the indigenous movement, made water one of their key demands. For instance, the Urban Forum fought for a prohibition of water cuts on public schools and hospitals; organizations from Guayaquil demanded that all water debts for domestic water supply of the poor be abolished and farmer unions fought for a more just distribution of irrigation water. The indigenous movement put forward most of its historic demands that had already been presented for years in their water law proposal. As put by the president of the Constituent Assembly

We had a high participation and mobilization of society. Their presence and their contributions were substantial. I don't want to minimize the work of the colleagues of the Assembly, but I think that the contributions of the committed civil society groups that have been engaged in the defence of water for years enabled us to consolidate a very solid position (March, 2011).

Most of the proposals from civil society coincided on the basic principles such as the human right to water, the non-private character of water, participation, public and communitarian water management, and the recognition of customary water rights systems in community managed irrigation. Amongst the different groups that struggled for the inclusion of their demands in the Constitution and later the water law, as García (2010) puts it 
... there are many more consensus and complementarities than differences. The paradox is that different organisations, platforms or institutions with very similar proposals have not been able to find consensus and that each one arrived to the Assembly through their own paths (p. 174).

These included the indigenous movement which, although allegedly side-lined in most discussions of the constituent assembly (Petras 2008), framed the gains of the constitution 'as the result of long struggles of diverse social movements [... stressing that]...the new constitution embodied very important social, cultural, political, economic, and environmental advances, including plurinationality, interculturality, collective rights, rights of nature [...] water as a human right...' (Becker 2011, p. 60). The confluence of all these proposals can be seen as the result of the increased global, national and local centrality that water and its governance gained in a plurality of social spaces to which WRF, CAMAREN and its capacity building efforts contributed.

\section{WRF's Challenges in the New National and International Context}

The development and positioning of WRF took place in a national and international context that was favourable for development NGOs, and its most important policy achievements came about through a national process of change which enabled NGOs and civil society organizations to actively participate in the formulation of a new national legal framework, but since then the context has changed. The Ecuadorian economy started to recuperate since the early 2000s, and since 2007, the 'new' government of Rafael Correa has made great investments in public infrastructure, increased the minimum wages, improved the provision of social services and greatly invested in rural development programmes (Becker 2011, Boelens et al. 2013). These investments have further reduced the number of people that live in extreme poverty in the country, decreasing the 'need' for international funding of development projects. This has affected the flow of funds to NGOs that execute these programmes. COSUDE has 'departed' from Ecuador, SNV stopped its water programme and many other international NGOs have either left the country or greatly reduced their support programmes. This has made it harder for WRF and its participating NGOs to secure continued funding for their activities. At the same time, and maybe more challenging is the fact that after its initial democratic initiatives which peaked during the process that led to the 2008 Constitution, the government of Rafael Correa has become more centralistic and repressive, increasing its control over the funding and activities of NGOs (Boelens et al. 2013), and, while many of the important achievements of the 2008 Constitution are remarkable in legal terms (Roa-García et al., 2013), their implementation and materialization remain in many aspects white elephants (Boelens et al. 2013). In this new socio-political and historical context, WRF has maintained its networking, discussion and 
research activities, but its capacity to exert direct political agency at national level has been greatly curtailed.

\section{Conclusions}

According to Biekart (2007), in the last decades, European NGOs and donor organization have financed a large number of NGOs (and their activities) in the Global South. One of the main spear points of much of this support has been the development of 'political participation' from civil society. With the aim of developing the voice of the marginalized and promote active citizenship through democracy, several long-term programmes have been financed in Latin America. Yet the impact of these efforts on the formation of civil society organizations remains disputed (Chahim and Prakash 2014).

The case of WRF shows how the shared efforts of national NGOs that were supported by international funding were able to create and stimulate a critical mass that has significantly contributed to the water governance policy debates in Ecuador. As such, it has fomented democracy by enabling a multiplicity of individuals, NGOs, state representatives and grassroots organizations to take part in national water governance debates. This points at the important role NGOs can play in the development of third sector political agency in the water governance domain. The key to this development was the creation of a broad network that includes development NGOs, grassroots organizations, academics and state representatives. In this way, WRF was able to establish effective relations with international, governmental and many civil society organizations in a favourable historically specific international context, which created a unique possibility for democratic participation in national policy making through the 2008 Constitutional process. At present, in a transformed international context, the possibilities of WRF to change governmental policies has been curtailed. Nevertheless, its networking, capacity and awareness building activities, which lie at the heart of its public legitimacy, harbour the possibility to bring about changes to governmental policies when the sociopolitical context allows. In terms of the capacity of NGOs to bring about change and democracy to societies in Latin America, this case suggests that development NGOs and international efforts to support these can positively contribute to a deepening of democracy through the empowerment of grassroots organizations and the broader third sector, but that their capacity to bring about changes in public policies very much hinges on the historical context in which these operate.

Acknowledgments This research was funded by the Netherlands Organization for Scientific Research (NWO) through its division of Science for Global Development (WOTRO) under project number W 01.65.308.00: 'Struggling for water security: Social mobilization for the defence of water rights in Peru and Ecuador'. We thank the editors and anonymous reviewers for the insightful comments on earlier drafts. The usual disclaimers apply.

Open Access This article is distributed under the terms of the Creative Commons Attribution License which permits any use, distribution, and reproduction in any medium, provided the original author(s) and the source are credited. 


\section{References}

Acosta, A. (2010). El agua, un derecho humano fundamental. In A. Acosta \& E. Martínez (Eds.), Agua; Un derecho humano fundamental (pp. 7-45). Quito: Abya-Yala.

Alvarez, S. E., Dagnino, E., \& Escobar, A. (1998). Introduction: The cultural and the political in Latin American social movements. In S. E. Alvarez, E. Dagnino, \& A. Escobar (Eds.), Cultures of politics/ politics of cultures: Re-visioning Latin American social movements (pp. 1-29). Oxford: Westview Press.

Andolina, R. (2012). The values of water: Development cultures and indigenous cultures in highland Ecuador. Latin American Research Review, 47(2), 3-26.

Andolina, R., Laurie, N., \& Radcliffe, S. (2009). Indigenous development in the Andes; culture, power and transnationalism. Durham: Duke University Press.

Assies, W. (2003). David versus Goliath in Cochabamba: Water rights, neoliberalism, and the revival of social protest in Bolivia. Latin American Perspectives, 30(3), 14-36.

Bebbington, A. (1997a). New states, new NGOs? Crises and transitions among rural development NGOs in the Andean region. World Development, 25(11), 1755-1765.

Bebbington, A. (1997b). Reinventing NGOs and rethinking alternatives in the Andes. Annals of the American Academy of Political and Social Science, 554, 117-134.

Bebbington, A. (1997c). Social capital and rural intensification: Local organizations and islands of sustainability in the rural Andes. Geographical Journal, 163(2), 189-197.

Bebbington, A. (2004). NGOs and uneven development: Geographies of development intervention. Progress in Human Geography, 28(6), 725-745.

Bebbington, A., \& Farrington, J. (1993). Governments, NGOs and agricultural development: Perspectives on changing inter-organisational relationships. Journal of Development Studies, 29(2), 199-219.

Becker, M. (2008). Indians and leftist in the making of Ecuador's modern indigenous movements. Durham: Duke University Press.

Becker, M. (2011). Correa, indigenous movements, and the writing of a new constitution in Ecuador. Latin American Perspectives, 38(1), 47-62.

Biekart, K. (2007). Learning from Latin America: Recent trends in European NGO policy-making. In A. Bebbington, S. Hickey, \& D. Mitlin (Eds.), Can NGOs make a difference? The challenge of development alternatives (pp. 71-89). London: Zed Books.

Boelens, R. (2002). Recepies and resistance. Peasants' rights building and empowerment in the Licto Irrigation System, Ecuador. In R. Boelens \& P. Hoogendam (Eds.), Water rights and empowerment. Assen: Van Gorcum.

Boelens, R. (2008a). The rules of the game and the game of the rules: Normalization and resistance in Andean water control, Irrigation and Water Engineering Group. Wageningen: Wageningen University.

Boelens, R. (2008b). Water rights arenas in the andes: Upscaling networks to strengthen local water control. Water Alternatives, 1(1), 48-65.

Boelens, R., Bustamante, R., \& Perreault, T. (2010). Networking strategies and struggles for water control: From water wars to mobilizations for day-to-day water rights defence. In R. Boelens, D. Getches, \& A. Guevara-Gil (Eds.), Out of the mainstream. Water rights, politics and identity (pp. 281-305). London: Earthscan.

Boelens, R., Hoogesteger, J., \& Baud, M. (2013). Water reform governmentality in Ecuador: Neoliberalism, centralization, and the restraining of polycentric authority and community rulemaking. Geoforum. doi:10.1016/j.geoforum.2013.07.005.

Boelens, R., Hoogesteger, J., \& Rodriguez de Francisco, J. C. (2014). Commoditizing water territories: The clash between Andean water rights cultures and payment for environmental services policies. Capitalism, Nature, Socialism, 25(3), 84-102.

Borras, S. M, Jr, Edelman, M., \& Kay, C. (2008). Transnational agrarian movements: Origins and politics, campaigns and impact. Journal of Agrarian Change, 8(2-3), 169-204.

Brinkerhoff, J. M., Smith, S. C., \& Teegen, H. (2007). Beyond the "Non": The strategic space for NGOs in development. In J. M. Brinkerhoff, S. C. Smith, \& H. Teegen (Eds.), NGOS and the millennium development goals: Citizen action to reduce poverty (pp. 53-80). New York: Palgrave Macmillan.

Brown, T. (2014). Negotiating the NGO/Social Movement Dichotomy: Evidence from Punjab, India. VOLUNTAS: International Journal of Voluntary and Nonprofit Organizations, 25(1), 46-66. 
Brown, L. D., \& Kalegaonkar, A. (2002). Support organizations and the evolution of the NGO Sector. Nonprofit and Voluntary Sector Quarterly, 31(2), 231-258.

Carroll, T. F., \& Bebbington, A. J. (2001). Peasant federations and rural development policies in the andes. Policy Sciences, 33(3-4), 435-457.

CentroCarter. (2008). Informe sobre la Asamblea Constituyente de la República del Ecuador (p. 69). Centro Carter: Quito.

Chahim, D., \& Prakash, A. (2014). NGOization, foreign funding, and the Nicaraguan civil society. Voluntas, 25(2), 487-513.

CONAIE. (1996). Ley de Aguas. Quito: CONAIE.

Cremers, L., Ooijevaar, M., \& Boelens, R. (2005). Institutional reform in the Andean irrigation sector: Enabling policies fpr strengthening local rights and water management. Natural Resources Forum, 29(1), 37-50.

Dagnino, E. (2007). Challenges to participation, citizenship and democracy: Perverse confluence and displacement of meanings. In A. Bebbington, S. Hickey, \& D. Mitlin (Eds.), Can NGOs make a difference? The challenge of development alternatives (pp. 55-70). London: Zed Books.

de la Torre, C., \& Conaghan, C. (2009). The hybrid campaign: Tradition and modernity in Ecuador's 2006 presidential election. International Journal of Press/Politics 14(3), 335-352.

Edelman, M. (1999). Peasants against globalization: Rural social movements in Costa Rica. Stanford: Stanford University Press.

Edelman, M. (2008). Transnational organizing in agrarian Central America: Histories, challenges, prospects. Journal of Agrarian Change, 8(2-3), 229-257.

Fernández, N., \& Buitrón Cisneros, R. (2012). The right to water and sanitation in Ecuador: Progress, limitations, and challenges. Environmental Justice, 5(2), 77-81.

Foro de los Recursos Hídricos (FORO). (2005). Proyecto de Ley Reformatoria de la Codificación de la Ley de Aguas y Leyes conexas: 6 aspectos claves. Quito: Foro de los Recursos Hídricos.

Foro de los Recursos Hídricos (FORO). (2008). Una Ley que Garantice el Derecho al Agua. Quito: Foro de los Recursos Hídricos.

Foro de los Recursos Hídricos (FORO). (2013). Séptimo Encuentro Nacional: Acuerdos, Propuestas y Conclusiones. Quito: Foro de los Recursos Hídricos.

Fowler, A. (2000). NGO futures: Beyond aid: NGDO values and the fourth position. Third World Quarterly, 21(4), 589-603.

García, D. (2009). Del Caracol al Milpiés, El Foro de Recursos Hídricos del Ecuador y el agua en la nueva Constitución, Unpublished research report.

García, D. (2010). Una Constitución hecha de agua. In A. Acosta \& E. Martínez (Eds.), Agua: Un derecho humano fundamental (pp. 173-201). Abya-Yala: Quito.

Gaybor, A. (2008). El despojo del agua y la necesidad de una transformación urgente. Quito: Foro de los Recursos Hídricos.

Gaybor, A. (2010). Acumulación capitalista en el campo y despojo del agua, in: Acosta, A., Martínez, E. (Eds.), Agua: Un derecho humano findamental (pp. 47-66). Abya-Yala: Quito.

Harris, L. M., \& Roa-García, M. C. (2013). Recent waves of water governance: Constitutional reform and resistance to neoliberalization in Latin America (1990-2012). Geoforum, 50(0), 20-30.

Heckathorn, D. D. (1997). Respondent-driven sampling: A new approach to the study of hidden populations. Social Problems, 44(2), 174-199.

Hey, J., \& Klak, T. (1999). From protectionism towards neoliberalism: Ecuador across four administrations (1981-1996). Studies in Comparative International Development (SCID), 34(3), 66-97.

Hoogesteger, J. (2012). Democratizing water governance from the grassroots: The development of Interjuntas-Chimborazo in the Ecuadorian Andes. Human Organization, 71(1), 76-86.

Hoogesteger, J. (2013a). Trans-forming social capital around water: Water user organizations, water rights, and nongovernmental organizations in Cangahua, the Ecuadorian Andes. Society and Natural Resources, 26(1), 60-74.

Hoogesteger, J. (2013b). Social capital in water user organizations of the Ecuadorian highlands. Human Organization, 72(4), 347-357.

Hoogesteger, J. (2013c). Movements against the current: Scale and social capital in peasants' struggles for water in the Ecuadorian Highlands, Water Resources Management Group. Wageningen University, Wageningen, p. 193.

Hoogesteger, J. (2014). Building blocks for users' participation in water governance: Irrigators' organizations and state reforms in Ecuador. International Journal of Water Governance, 2(1), 1-18. 
Jameson, K. P. (2011). The indigenous movement in Ecuador: The struggle for a plurinational state. Latin American Perspectives, 38(1), 63-73.

Kilby, P. (2006). Accountability for empowerment: Dilemmas facing non-governmental organizations. World Development, 34(6), 951-963.

Lincoln, Y., \& Guba, E. (1985). Naturalistic inquiry. Newbury Park, CA: Sage.

Machado-Puertas, J. C. (2008). Ecuador: Until there were none. Revista de Ciencia Politica, 28(1), $189-215$.

Mason, J. (2002). Qualitative researching. London: SAGE Publications.

Mitlin, D. (2008). With and beyond the state-Co-production as a route to political influence, power and transformation for grassroots organizations. Environment and Urbanization, 20(2), 339-360.

Mitlin, D., Hickey, S., \& Bebbington, A. (2007). Reclaiming Development? NGOs and the challenge of alternatives. World Development, 35(10), 1699-1720.

Mosquera, T. (2011). Hacia la formulación de una política nacional y un nuevo modelo de gestión del riego en el Ecuador: Propuestas desde las organizaciones de usuarios. Quito: Foro de los Recursos Hídricos.

Ostrom, E. (1990). Governing the commons: The evolutions of institutions for collective action. Cambridge: Cambridge University Press.

Perreault, T. (2003). Changing places: Transnational networks, ethnic politics, and community development in the Ecuadorian Amazon. Political Geography, 22(1), 61-88.

Perreault, T. (2006). From the Guerra del Agua to the Guerra del Gas: Resource governance, neoliberalism and popular protest in Bolivia. Antipode, 38(1), 150-172.

Perreault, T. (2008). Custom and contradiction: Rural water governance and the politics of usos y costumbres in Bolivia's irrigators' movement. Annals of the Association of American Geographers, 98(4), 834-854.

Petras, J. (2008). Social movements and alliance-building in Latin America. Journal of Peasant Studies, 35(3), 476-528.

Petras, J., \& Veltmeyer, H. (2006). Social movements and the state: Political power dynamics in Latin America. Critical Sociology, 32(1), 83-104.

Rap, E. (2006). The success of a policy model: Irrigation management transfer in Mexico. Journal of Development Studies, 42(8), 1301-1324.

República del Ecuador. (2008). Constitución del Ecuador. República del Ecuador.

Roa-García, M. C., Urteaga-Crovetto, P., \& Bustamante-Zenteno, R. (2013). Water laws in the Andes: A promising precedent for challenging neoliberalism. Geoforum. doi:10.1016/j.geoforum.2013.12.002.

Sacouman, N. (2012). Paths of local development: Culture, context, power, and the role of nongovernmental organizations. Voluntas, 23(4), 899-919.

Srinivas, N. (2009). Against NGOs? A critical perspective on nongovernmental action. Nonprofit and Voluntary Sector Quarterly, 38(4), 614-626.

Suhardiman, D., \& Giordano, M. (2014). Is there an alternative for irrigation reform? World Development, 57, 91-100.

Tiaguaro-Rea, Y. (2012). From paper to reality: Irrigation Management Transfer in the El Pisque irrigation system, Ecuador, Irrigation and Water Engineering. Wageningen: Wageningen University.

Unidad de Participación Social de la Asamblea Constituyente (UPS). (2008). Informe de Actividades. Quito: Asamblea Constituyente.

Uvin, P., \& Miller, D. (1996). Paths to scaling-up: Alternative strategies for local nongovernmental organizations. Human Organization, 55(3), 344-354.

Yashar, D. J. (2005). Contesting citizenship: indigenous movements, the state, and the postliberal challenge in Latin America. Cambridge: Cambridge University Press. 